\title{
Magnetic anomalies and metamorphic boundaries in the southern Nagssugtoqidian orogen, West Greenland
}

\author{
John A. Korstgård, Bo Møller Stensgaard and Thorkild M. Rasmussen
}

Within the southern Nagssugtogidian orogen in West Greenland metamorphic terrains of both Archaean and Palaeoproterozoic ages occur with metamorphic grade varying from low amphibolite facies to granulite facies. The determination of the relative ages of the different metamorphic terrains is greatly aided by the intrusion of the $2 \mathrm{G}$ a Kangâmiut dyke swarm al ong a N N E trend. In Archaean areas dykes cross-cut gneiss structures, and the host gneisses are in amphibolite to granulite facies. Along I tilleq strong shearing in an $\mathrm{E}-\mathrm{W}$-oriented zone caused retrogression of surrounding gneisses to low amphibolite facies. W ithin this Itivdleq shear zone Kangâmiut dykes follow the E-W shear fabrics giving the impression that dykes were reoriented by the shearing. However, the dykes remain largely undeformed and unmetamorphosed, indicating that the shear zone was established prior to dyke emplacement and that the orientation of the dykes here was governed by the shear fabric. M etamorphism and deformation north of Itilleq involve both dykes and host gneisses, and the metamorphic grade is amphibolite facies increasing to granulite facies at the northern boundary of the southern N agssugtogidian orogen. H ere a zone of strong deformation, the lkertôq thrust zone, coincides roughly with the amphibolite-granulite facies transition. Total magnetic field intensity anomalies from aeromagnetic data coincide spectacularly with metamorphic boundaries and reflect changes in content of the magnetic minerals at facies transitions. Even the nature of facies transitions is apparent. Static metamorphic boundaries are gradual whereas dynamic boundaries al ong deformation zones are abrupt.

Keywords: aeromagnetic data, magnetic anomalies, metamorphic facies, Nagssugtoqidian orogen, W est G reenland

\begin{abstract}
J.A.K., D epartment of Earth Sciences, University of Aarhus, H øegh-G uldbergsgade 2, D K-8000 Århus C, D enmark. E-mail: john.korstgard@geo.au.dk

B.M.S. \& T.M.R., Geological Survey of D enmark and G reenland (GEUS), Ø ster Voldgade 10, DK-1350 Copenhagen K, $D$ enmark.
\end{abstract}

The establishment of the Palaeoproterozoic Nagssugtoqidian orogen in West G reenland (Ramberg 1949) is based on the deformation and metamorphism of the Kangâmiut dykes, dated at $2.04 \mathrm{Ga}$ by Nutman et al. (1999). South of the southern N agssugtogidian front (SN F in Fig. 1), in the southern $N$ agssugtogidian foreland, Kangâmiut dykes are undeformed and cross-cut gneiss structures. N orth of the front, gneisses and dykes have been metamorphosed and deformed together during the $\mathrm{Nagssugtogidian}$ orogeny. Here, gneiss structures and dyke margins are concordant and dykes transformed into amphibolites. This is the simple story upon which Ramberg (1949) based his definition of the ' $\mathrm{N}$ agssugtogides'. Ramberg also divided the $\mathrm{N}$ agssugtogidian orogen into three metamorphic complexes based on the metamorphic grade of the rocks. Thus the Egedesminde complex was the northernmost amphibolitefaciescomplex, thel sortoq complex the central granulite facies complex, and the Ikertôq complex the southernmost amphibolite facies complex. The current division of the orogen (Fig. 1) is based on structural criteria, and division boundaries now follow major structural features (M arker et al. 1995). The current division therefore deviates considerably from Ramberg's original division for the northern and central $N$ agssugtogidian orogen, whereas the 


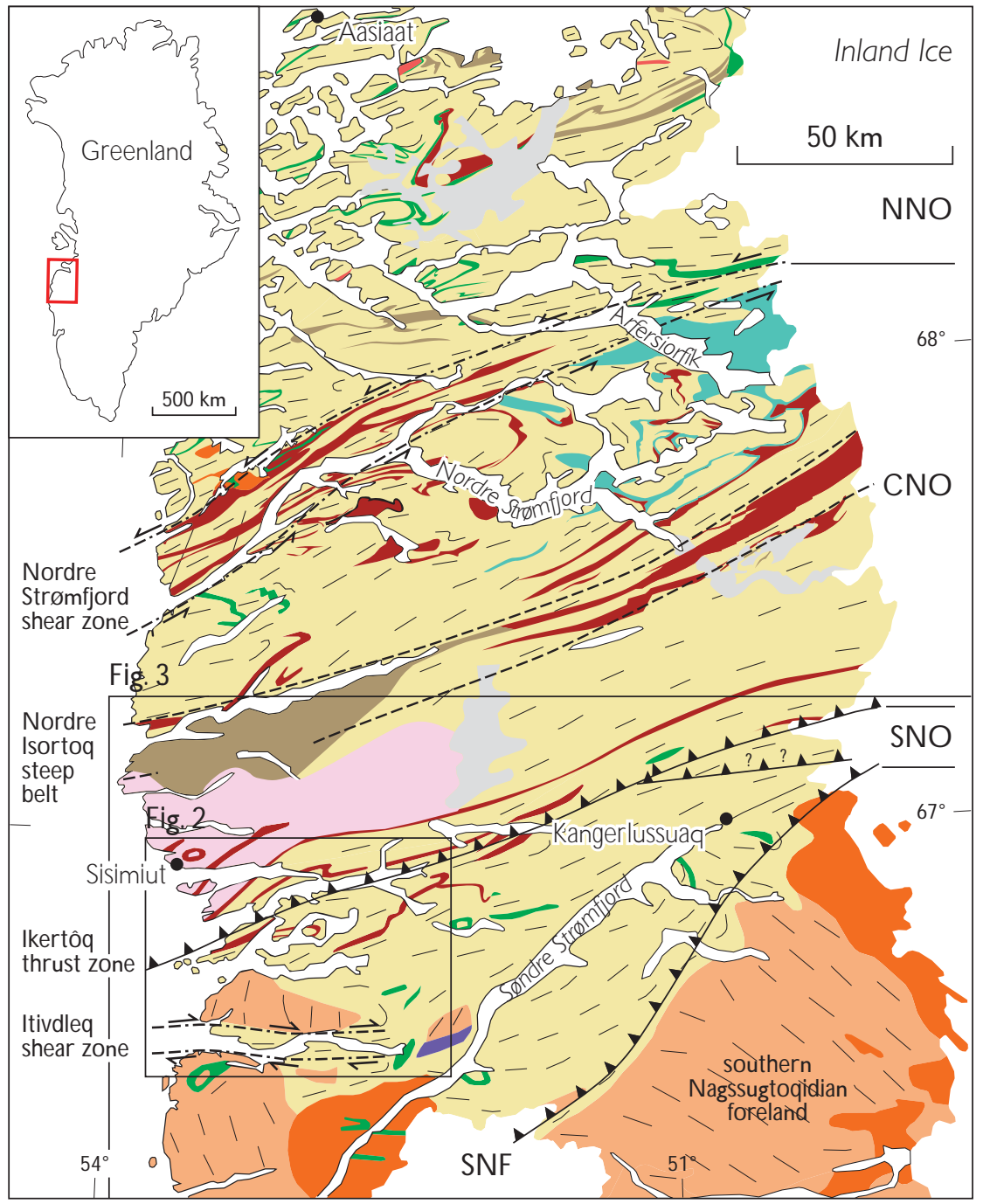

$\mathrm{N}$ agssugtogidian orogen

Sisimiut char nockite (Palaeoproterozoic)

Arfersiorfik quartz diorite (Palaeo proterozoic)

Orthogneiss (Archaean, reworked)

Metasedimentary rocks (Palaeoproterozoic,

may include A rchaean components)

Metasedimentary rocks (Archaean, may include Proterozoic components)

Amphibolite

A northosite and ultrabasic rocks

\section{Q uaternary}

$\square$ Surficial deposits

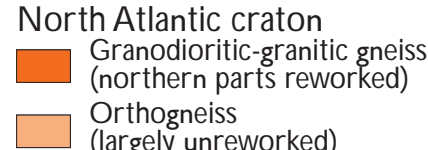

N orth A tlantic craton

(northern parts reworked)

(largely unreworked)
Fig. 1. Schematic geology of the southern part of the $N$ agssugtogidian orogen and adjacent forelands (modified from Escher \& Pulvertaft 1995 and M arker et al. 1995). SN O, southern $N$ agssugtogidian orogen; $\mathrm{CN} \mathbf{O}$, central Nagssugtogidian orogen; N N O, northern Nagssugtogidian orogen; SN F, southern Nagssugtogidian front. The locations of thrust and shear zones are defined from trends observed in the aeromagnetic data; note that the $\mathrm{E}-\mathrm{W}$ trending thrust zone with question marks north of Kangerlussuaq is uncertain, as this structure has not been confirmed by geological mapping. Black frames show the locations of Figs 2, 3. southern $\mathrm{N}$ agssugtogidian orogen correspondsalmost exactly to Ramberg's original Ikertôq complex.

The southern $\mathrm{N}$ agssugtogidian orogen (SN $\mathrm{O}$ in Fig. 1) in the coastal region between Sisimiut and Itilleq consists mainly of quartzofeldspathic gneisses of granodioritic to tonalitic composition. Several supracrustal layers occur, particularly in the northern part of the SN O. The supracrustal rocks are mainly garnet-biotite schists, rusty weathering biotite gneisses and amphibolites. The metamorphic gradeis low amphibolite facies to granulitefacies, and due to the fortunate timing of the intrusion of the Kangâmiut dykes it is possible to assign relative ages to the different metamorphic terrains in the region.

\section{Pre-dyke metamorphism and deformation}

South of and immediately north of I tilleq, the Kangâmiut dykes are largely undeformed, unmetamorphosed and 
Fig. 2. Correlation between metamorphic facies and aeromagnetic anomaly patterns in the Itilleq-I kertooq region. White lines indicate approximate metamorphic facies boundaries based on geological field work; labels A-J are explained in the text. A: Distribution and relative ages of metamorphic facies. B: Total intensity magnetic field anomaly map. Shadow of magnetic field pattern modelled from a light source with inclination $45^{\circ}$ and declination $315^{\circ}$.
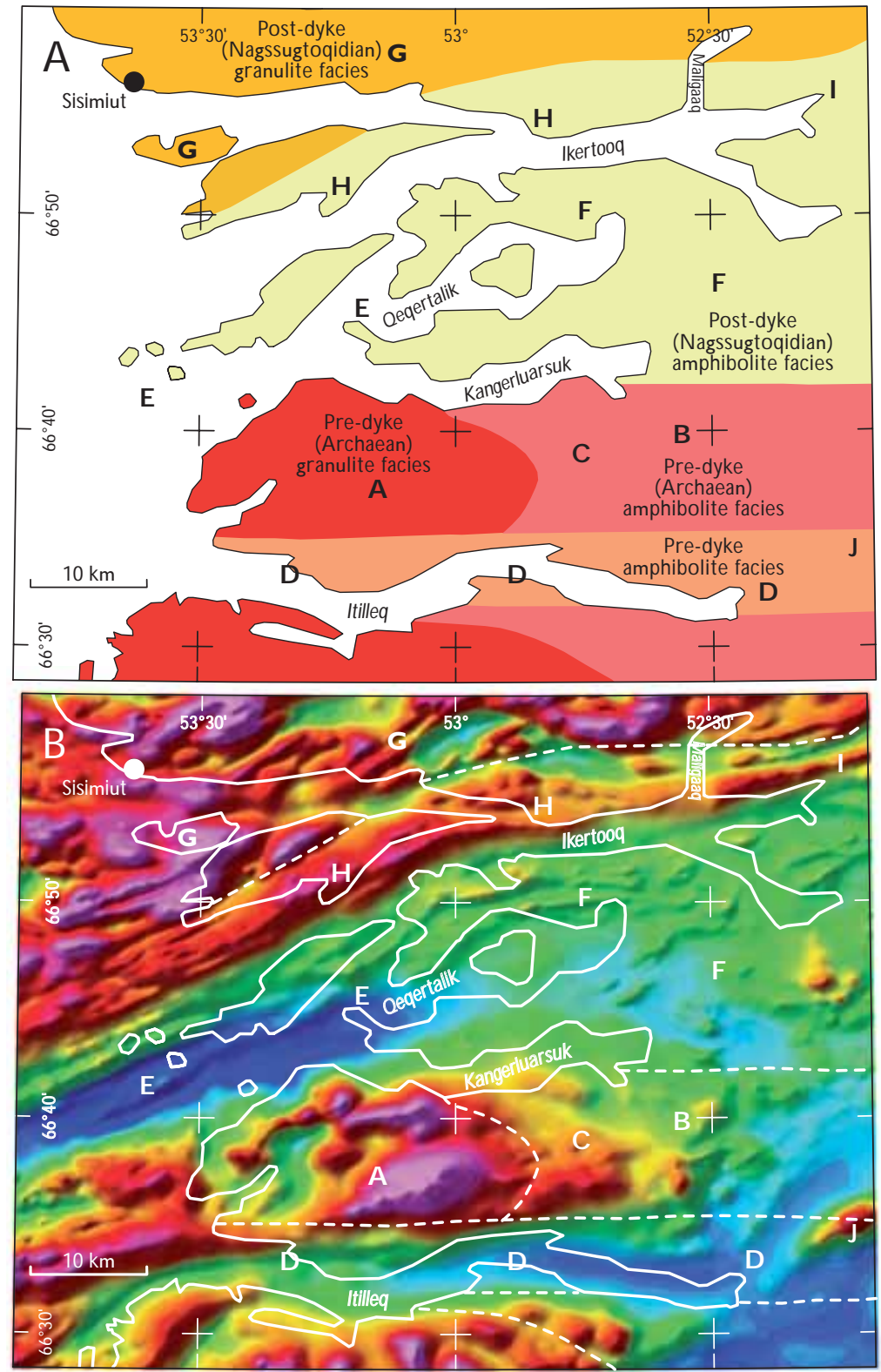

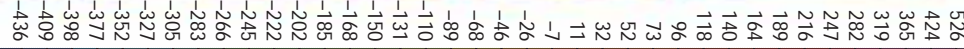
$[\mathrm{nT}]$ cross-cut gneiss structures. The main dyke direction is N N E-SSW, and a subordinatedirection isE-W to ESEW N W (Fig. 1). U pon entering the Itilleq area, the dyke trends areE-W, parallel to thefjord. This changein trend also corresponds to a change in foliation trend in the host gneisses. H owever, the dykes are still largely und eformed and unmetamorphosed within thisE-W trend. Themetamorphic grade of host gneisses north and south of Itilleq is granulite facies in western parts and amphibolite facies in eastern parts (Fig. 2A). H owever, all along the E-W trend in Itilleq, gneisses are in low amphibolite facies.

The dyke behaviour in the Itilleq region led to the interpretation that prior to intrusion of the Kangâmiut dykes the area wasstabilised in amphibolite-granulitefacies with a variable northerly trend of the foliation ( $G$ rocott 1979; Korstgård 1979). At some point prior to dyke intrusion an $\mathrm{E}-\mathrm{W}$ zone of strong deformation was established along Itilleq, downgrading gneisses to low amphibolitefacies (epidote-muscovite). W ithin this I tivdleg shear zone, dykes intruded along the shear fabrics and show a variety of primary pinch-and-swell structures (N ash 1979). 0 utside the shear zone, dyke margins are straight-sided indicating that dykes intruded al ong brittle fractures. 


\section{Post-dyke metamorphism and deformation}

Farther north of Itilleq, from Kangerluarssuk and northwards (Fig. 2A), dykes arethoroughly deformed and parallel to country rock structures. Both dykes and country rock structures are in amphibolite facies. Foliation trends are variableEN E-W SW around west-plunging fold axes.

Continuing northwards themetamorphic grade increases and reaches granulitefacies north of I kertooq fjord (Fig. 2A). In addition, gneiss structures and metamorphosed dykes take on a pervasive $\mathrm{E}-\mathrm{W}$ orientation (I kertôq thrust zone, Fig. 1) with a steeply $\mathrm{N}$-dipping foliation and $\mathrm{N}$ plunging stretching lineations.

The interpretation of field observations in the northern SN $O$ is that the metamorphism and deformation are post-dyke, the metamorphic transition is prograde, and the Ikertôq thrust zone represents a zone of southward ductile thrusting whereby deeper-seated rocks are brought up from the north.

\section{Facies transitions}

Within theltilleq-Ikertooq region four types of faciestransitions or boundaries are recognised. Two of these are prograde and two are associated with strong deformation in ductile shear zones.

The amphibolite-granulite facies transition in the Archaean areas around Itilleq is prograde and static in the sense that the boundary was not established as a result of a deformational event, but reflects static equilibration of the mineral assemblages to the conditions that prevailed when the rocks were at their deepest crustal level. D uring later uplift the rocks escaped any significant metamorphic changes due to the absence of deformation, and the metamorphism reflects their initial Archaean state.

The granulite to low amphibolite facies and amphibolite to low amphibolite facies transitions al ong Itilleq are retrograde and dynamic in the sense that they were established as a direct consequence of the deformation along the Itivdleq shear zone. M ineral assemblages in the shear zone were equilibrated to the metamorphic conditions of a higher crustal level than reflected in the surrounding gneisses, and the shearing triggered this re-equilibration.

The amphibolite granulite facies transition north of I kertoog is both prograde and dynamic. It can be considered as a displaced prograde and static transition brought up into a sub-vertical position by the overthrust movement along the lkertôq thrust zone (Fig. 1).

\section{Magnetisation}

Comparing the magnetic anomaly map for the area (Fig. 2B) with the metamorphic map (Fig. 2A) a striking coincidence of magnetisation and metamorphic boundaries is evident. M ore information on themagnetic field data and the geological interpretations can be found in Rasmussen \& van G ool (2000), Nielsen (2004) and N ielsen \& Rasmussen (2004).

Strong magnetisation in pre-dyke Archaean granulite facies areas just north of Itilleq ( $A$ in Fig. 2B) is attributed to a higher content of magnetite or other magnetic minerals. A likely explanation for this is production of magnetite by the breakdown of hydrous (Fe, M g)-Al-silicates (e.g. biotite, amphibole) during the transition from amphibolites to granulite facies according to the general reaction: hydrous (Fe, M g)-Al-silicates $\pm \mathrm{SiO}_{2} \pm \mathrm{O}_{2}=\mathrm{K}$ feldspar $+(\mathrm{Fe}, \mathrm{M} \mathrm{g})$-silicates \pm magnetite $+\mathrm{H}_{2} \mathrm{O}$. Thelower magnetisation in pre-dyke Archaean amphibolitefacies areas (B in Fig. 2B) relative to pre-dyke Archaean granulitefacies areas indicates no additional production of magnetite. The gradual increase in magnetic intensity ( $C$ in Fig. 2B) marks the gradual prograde facies transition.

The elongate low magnetic anomaly coincident with the Itivdleq shear zone (D in Fig. 2B) is caused by extensive breakdown of magnetic minerals. This may be due to chemical breakdown during metamorphic retrogression to pre-dyke amphibolite facies aided by circulating fluids in the shear zone, and mechanical destruction of themagnetic mineral grains. The abrupt changes in anomaly patterns from $D$ to A (Fig. 2B) across the metamorphic facies transition and deformation boundary are a response to the dynamic nature of this boundary.

Previously suggested possible shearing south of Ikertooq (E in Fig. 2B; G rocott 1979; Korstgård 1979) contemporaneous with the shearing at Itilleq ( $D$ in Fig. 2B) is supported by similarities in the character of the anomaly patterns. The post-dyke amphibolite facies areas at, and south of, I kertoog ( $F$ in Fig. 2B) indicate the Palaeoproterozoic retrogression to amphibolite facies and deformational reworking. T heboundary between the pre-dyke Archaean amphibolite facies and the post-dyke amphibolite facies areas does not have a well-defined magnetic signature (between $B$ and $F$ in Fig. 2B).

The increase in magnetisation north of I kertoog ( $G$ in Fig. 2B) corresponds to rocks metamorphosed under granulite facies conditions after dyke intrusion and brought up by overthrusting. The offset between the mapped facies boundary north of Ikertooq (Fig. 2A) and the boundary between high and low magnetisation ( $\mathrm{H}$ in Fig. 2B) can be explained as partially due to non-exposed post-dyke 


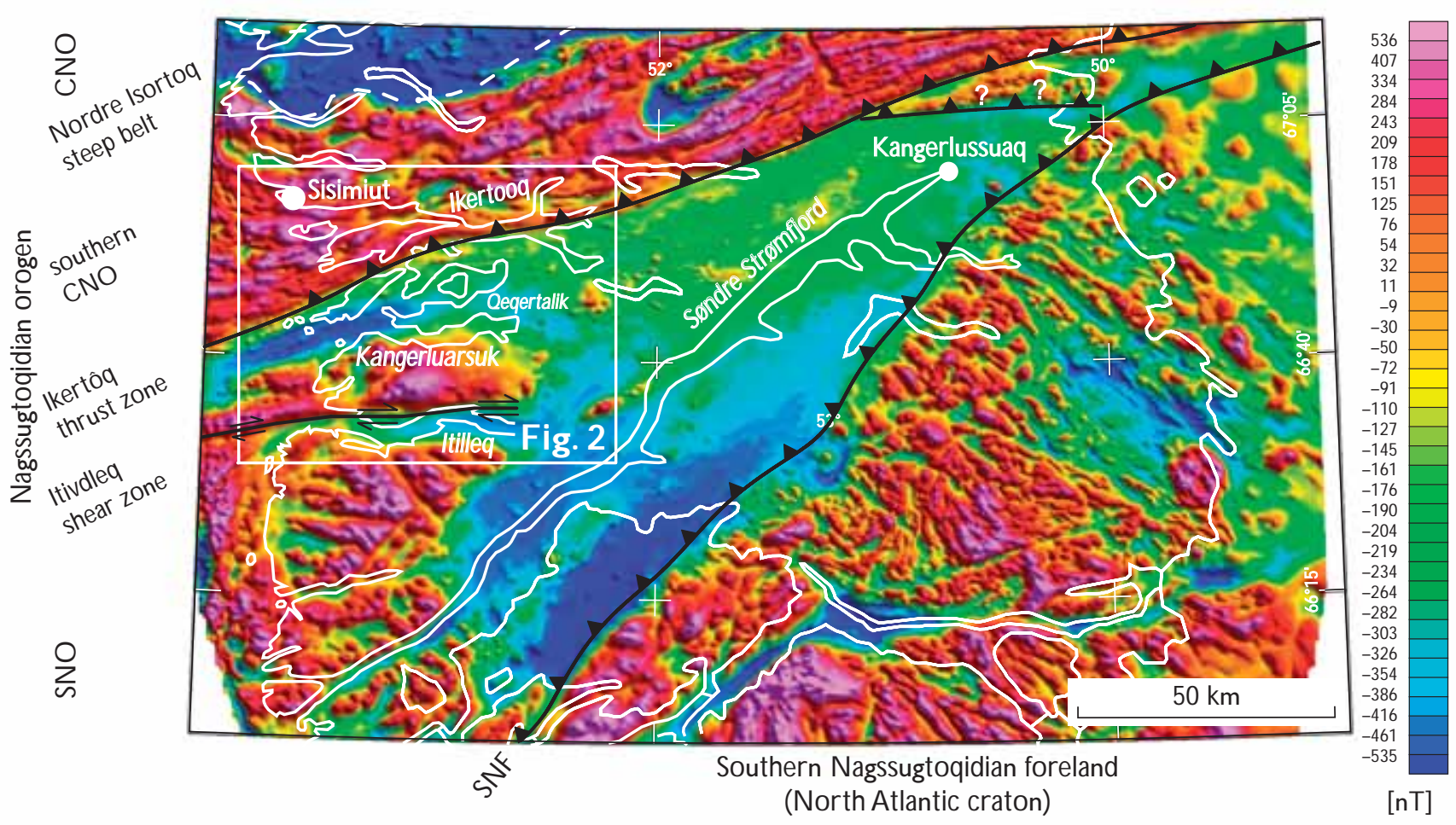

Fig. 3. Total intensity magnetic field anomaly map of the south-eastern part of the $\mathrm{N}$ agssugtogidian orogen and its foreland, with the location of the Itilleq-I kertooq region (white frame, Fig. 2). Abbreviations as for Fig. 1; shadow on magnetic data as for Fig. 2. The E-W-trending thrust zone with question marks north of Kangerlussuaq is uncertain, as this structure has not been confirmed by geological mapping.

granulitefacies rocks, and partially to the effect of stacked thrust panels of post-dykeamphiboliteand granulitefacies rocks with alternating low and high magnetic intensity anomalies (I in Fig. 2B). I solated high intensity anomalies can be correlated with distinct lithologies or intrusives (e.g. an anorthosite complex at J in Fig. 2B). The presence or absence of Kangâmiut dykes is not reflected in the aeromagnetic data.

Theobserved correlations between metamorphic facies, deformation and magnetisation can be extended to other areas of the SN 0 (Fig. 3) provided that the background gneisses are lithologically fairly homogeneous, as is generally the case in the southern Nagssugtoqidian orogen. Where gneiss lithologies are more variable, such as in the N ordre Isortoq steep belt (Fig. 1) and the N ordre Strømfjord shear zone (Sørensen et al. 2006, this volume) correlationstend to depend on lithology rather than metamorphic grade.

\section{Acknowledgements}

The authors thank Graham Leslie and Chris Pulvertaft for their concise and constructive reviews.

\section{References}

Escher, J.C. \& Pulvertaft, T.C.R. 1995: G eological map of Greenland, 1:2 500 000. Copenhagen: $G$ eological Survey of Greenland.

Grocott, J. 1979: Controls of metamorphic grade in shear belts. In: Korstgård, J.A. (ed.): Nagssugtogidian geology. Rapport Grønlands GeologiskeU ndersøgelse 89, 47-62.

Korstgård, J.A. (ed.) 1979: Nagssugtogidian geology. Rapport Grønlands $\mathrm{G}$ eologiske Undersøgelse 89, $146 \mathrm{pp}$.

M arker, M ., M engel, F., van Gool, J. \& field party 1995: Evolution of thePalaeoproterozoic N agssugtogidian orogen: D LC investigations in West Greenland. Rapport Grønlands $\mathrm{G}$ eologiske Undersøgelse 165, 100-105.

N ash, D. 1979: An interpretation of irregular dykeforms in theltivdleq shear zone, W est Greenland. In: Korstgård, J.A. (ed.): N agssugtogidian geology. Rapport Grønlands G eologiske Undersøgelse 89, 77-83.

Nielsen, B.M . 2004: Crustal architecture and spatial distribution of mineral occurrences in the Precambrian shield of central West $G$ reenland based on geophysical and geological data. D anmarks og G rønlands $G$ eologiske U ndersøgelse Rapport 2004/26, 63 pp., 8 appendices. Ph.D. thesis 2004. Department of Earth Sciences, University of Aarhus, D enmark.

Nielsen, B.M . \& Rasmussen, T.M . 2004: M ineral resources of the Precambrian shield of central West $\mathrm{G}$ reenland $\left(66^{\circ}\right.$ to $\left.70^{\circ} 15^{\prime} \mathrm{N}\right)$. Part 
3. Implications of potential field data for the tectonic framework. D anmarks og G rønlands G eologiske U ndersøgel se Rapport 2004/ 21, $165 \mathrm{pp}$.

N utman, A.P., Kal sbeek, F., M arker, M ., van Gool, J.A.M . \& Bridgwater, D. 1999: U-Pb zircon ages of K angâmiut dykes and detrital zirconsin metasedimentsin the Palaeoproterozoic $N$ agssugtoqidian O rogen (West G reenland): clues to the pre-collisional history of the orogen. Precambrian R esearch 93, 87-104.

Ramberg, H . 1949: On the petrogenesis of the gneiss complexes between Sukkertoppen and C hristianshaab, W est Greenland. M eddelelser fra D ansk Geologisk Forening 11, 312-327.
Rasmussen, T.M . \& van G ool, J.A.M . 2000: Aeromagnetic survey in southern West G reenland: project Aer omag 1999. Geology of G reenland Survey Bulletin 186, 73-77.

Sørensen, K., Korstgård, J .A., G lassley, W.E. \& Stensgaard, B.M . 2006: The N ordre Strømfjord shear zone and the Arfersiorfik quartz dioritein theinner Arfersiorfik, theN agssugtogidian orogen, W est Greenland. In: Garde, A.A. \& Kal sbeek, F. (eds): Precambrian crustal evolution and C retaceous- Pal aeogene faulting in West Greenland. G eological Survey of Denmark and Greenland Bulletin 11, 145-161 (this volume). 